\title{
SFRP5 Gene
}

National Cancer Institute

\section{Source}

National Cancer Institute. SFRP5 Gene. NCI Thesaurus. Code C105004.

This gene may play a role in determining the polarity of photoreceptor cells in the retina. 